Journal of Plant Production

Journal homepage: www.jpp.mans.edu.eg

Available online at: www.jpp.journals.ekb.eg

\title{
Effect of Nitrogen and Potassium Fertilizers on Wheat Productivity under Different Soil Moisture Contents
}

\author{
Shimaa A. Badawy ${ }^{1 *}$; S. Gh. R. Sorour ${ }^{1}$; S. Hamad ${ }^{2}$ and Asmaa F. Badawy ${ }^{2}$ \\ ${ }^{1}$ Agronomy Departement., Facalty of Agriculture, 33516 Kafrelshiekh University,kafrelsheikh, Egypt. \\ ${ }^{2}$ Field Crops Research Institute Agriculture Research Center. Giza, Egypt
}

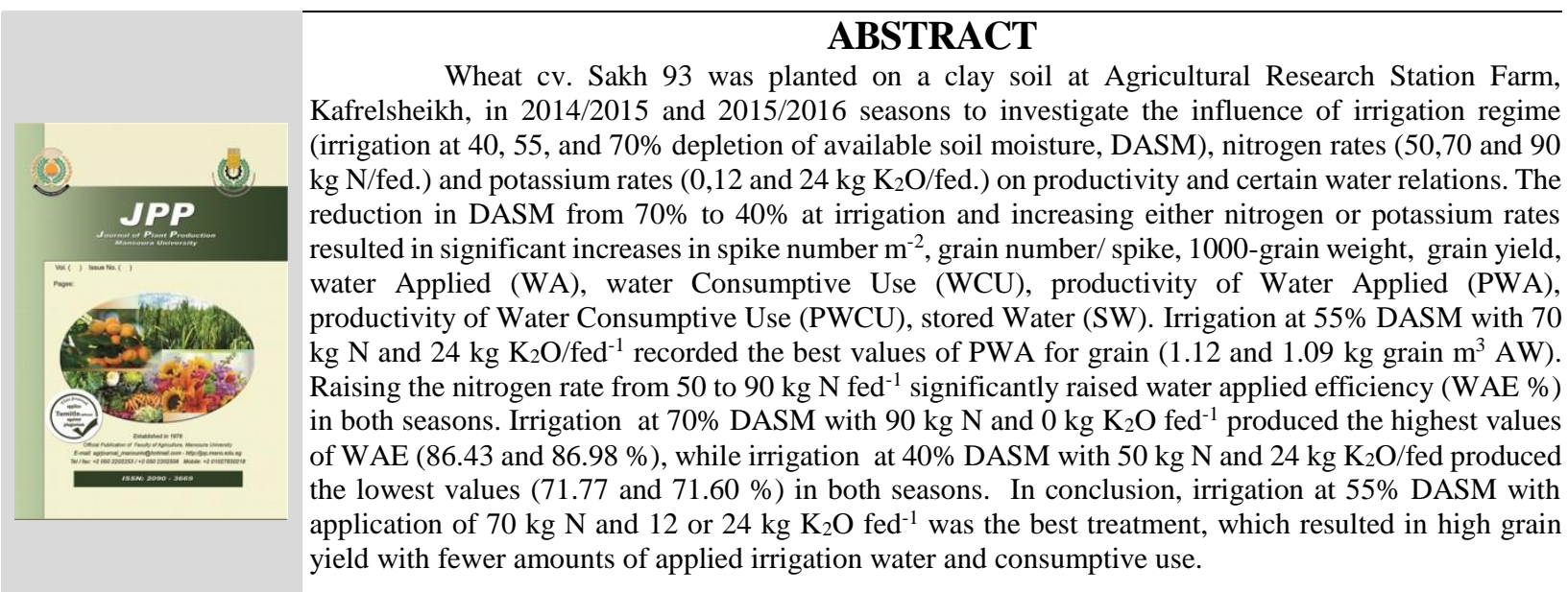

Keywords: Wheat productivity, nitrogen fertilization, potassium fertilization, soil moisture, Water Relations

\section{INTRODUCTION}

Water availably is the first prerequisite for a good yield. Water is the most important determinant of crop production in Egypt and in many parts of the world due to water shortages. In the following decades, the worldwide challenge will be to increase agricultural productivity while using less water. This can be partially achieved by increasing crop water use efficiency (Tari, 2016). Wheat production was increased by optimization of supplemental irrigation (Gharib and Meleha, 2016). Withholding irrigation water at different growth stages of wheat plant and irrigation based on measurements of soil moisture in several soil layers were studied by many previous researchers ( $\mathrm{Yi}$ et al., 2013).(Gharib and Meleha, 2016) observed no significant differences between full irrigation based on the soil water content at soil layer $0-60 \mathrm{~cm}\left(\mathrm{~W}_{1}\right)$ and $0-40 \mathrm{~cm}\left(\mathrm{~W}_{2}\right)$ in spikes number $\mathrm{m}^{-2}$, kernels number spike ${ }^{-1}$, 1000-kernel weight, straw yield and grain yield. They added that seasonal water applied amounted 2517 and $2025 \mathrm{~m}^{3} \mathrm{fed}^{-1}$ and water consumptive use values were 1584 and $1480 \mathrm{~m}^{3} \mathrm{fed}^{-1}$ over the two seasons for $\mathrm{W}_{1}$ and $\mathrm{W}_{2}$, respectively. Sun et al (2006) and Zhang et al (2006) revealed that reducing water application by $50 \mathrm{~mm}$ from wheat's water requirement had no effect on grain output and boosted water productivity. Karim et al. (1997) discovered that irrigation at \% available soil water depletion (ASMD) resulted in the maximum yield (4.71 t/ha) with $120 \mathrm{~kg} \mathrm{~N}$ application, but irrigation at \% ASMD resulted in a sufficient yield (4.13 t/ha) with the highest WUE (196.5 $\mathrm{kg} / \mathrm{ha} \mathrm{cm})$.
Fertilization is a significant and dynamic component of crop growth technology, with the greatest impact on the creation of the economic component of grain wheat yield (Ivanova et al., 2007). Nitrogen and potassium are major elements influencing wheat yield and quality. If there is insufficient nitrogen fertilizer, wheat output and quality would suffer; on the other hand, excessive nitrogen application will result in decreased nitrogen usage efficiency in wheat and increased environmental contamination (Dogan and Bilgili, 2010; Liu and Shi, 2013). A sufficient nitrogen supply enhances the protein content of vegetative organs as well as storage tissues and produces protein from carbs (Tari, 2016). The ideal nitrogen fertilizer levels for wheat vary greatly in quantity, ranging from 70 to $120 \mathrm{~kg} \mathrm{~N}$ fed-1 depending on environmental conditions (Mosaad and Fouda ,2016).

Potassium is a necessary nutrient and the most abundant cation in plants. $\mathrm{K}$ is required enzyme activation, protein synthesis, photosynthesis, osmoregulation, stomatal movement, energy transfer, phloem transport, cation-anion balance, and stress tolerance (Ngwako and Mashiqa 2013). According for to (Rahimi, 2012), potassium improves crop tolerance to water stress through a well-developed root system, as well as promotes optimum water uptake and improves water usage efficiency. Li et al. (2015) concluded that application of potassium improve leaf water potential, osmotic potential, turgor potential, spike length, number of grain per spike and grain yields under water stress. Gharib and Meleha (2016) discovered that applying K fertiliser reduced the detrimental impacts of not watering on yield and its 
components. They also stated that the application of $\mathrm{K}$ fertiliser had no influence on seasonal irrigation water or consumptive usage, but it boosted water productivity by boosting grain output.

The objectives of this work were to investigate the influence of irrigation regime, as well as nitrogen and potassium fertilizer rates, on wheat production and water relationship.

\section{MATERIALS AND METHODS}

Wheat cultivar Sakh 93 (Triticum aestivum L.) was grown on a clay soil at the farm of Agricultural Research Station, Kafr El-Sheikh Governorate (6 m altitude, $31^{\circ} 07$ latitude and $30^{\circ} 52^{-}$longitude) in 2015 and 2016 seasons, to determine the effect of soil moisture depletion, nitrogen and potassium fertilization on grain and straw yields and some water relations. The preceding crop was maize in the two seasons. The soils of the experimental field were clay with some water table of 70-95 cm in both seasons. The soil bulk density, field capacity and wilting point were determined in the experimental sites as given in Table 1. Some chemical properties of the experimental soil in the two seasons are presented in Table 2.

The experimental field was fertilized with $15.5 \mathrm{~kg}$ $\mathrm{P}_{2} \mathrm{O}_{5} /$ feddan in the form of calcium superphosphate $(15.5$ $\left.\% \mathrm{P}_{2} \mathrm{O}_{5}\right)$ during soil preparation. Irrigation treatments were started after the first irrigation (sowing irrigation). Three irrigation regimes were used at 40, 55 and $70 \%$ depletion of available soil moisture (DASM) at 0-60 cm soil depth. The actual irrigation requirement was estimated by drying soil samples for 24 hours at $110 \mathrm{C}^{0}$ and expressing the percentage of moisture as an oven dry weight basis. Soil samples were collected at each $15 \mathrm{~cm}$ soil depth up to $60 \mathrm{~cm}$ before and after each irrigation to calculate wheat's water consumptive use (WCU). Potassium fertilizer was applied with the rates of 0,12 and $24 \mathrm{~kg} \mathrm{~K}_{2} \mathrm{O} /$ feddan in the form of potassium sulphate $(48 \% \mathrm{~K} 2 \mathrm{O})$ at the second irrigation. Nitrogen fertilizer was given with the rates of 50,70 and $90 \mathrm{~kg}$ N/feddan in the form of urea $(46.5 \% \mathrm{~N})$ in two doses, $20 \%$ at sowing and $80 \%$ at the first irrigation (onset tillering stage).

Table 1. Field capacity, wilting point and bulk density for the experimental field in $2014 / 15$ and $2015 / 16$ season

\begin{tabular}{lcccccc}
\hline $\begin{array}{l}\text { Soil } \\
\text { depth } \\
\text { (cm) }\end{array}$ & \multicolumn{2}{c}{$\begin{array}{c}\text { Field capacity } \\
\text { \% }\end{array}$} & \multicolumn{2}{c}{ Wilting point } & \multicolumn{2}{c}{$\begin{array}{c}\text { Bulk density } \\
\text { (g/.cm }\end{array}$} \\
\hline $0-15$ & 42.04 & 43.64 & 22.42 & 23.68 & 1.19 & 1.13 \\
$15-30$ & 41.88 & 41.45 & 20.85 & 21.55 & 1.23 & 1.21 \\
$30-45$ & 38.91 & 38.98 & 19.72 & 21.22 & 1.29 & 1.21 \\
$45-60$ & 37.57 & 36.19 & 19.48 & 19.76 & 1.31 & 1.28 \\
Mean & 40.10 & 40.06 & 20.62 & 21.55 & 1.26 & 1.21 \\
\hline
\end{tabular}

Table 2. Chemical analysis of the experimental soil (0-30 cm depth) in 2014/15 and 2015/16season

\begin{tabular}{|c|c|c|c|c|c|c|}
\hline Season & $\underset{(1: 2.5)}{\text { pH }}$ & $\begin{array}{c}E C \\
\text { (ds } / \mathbf{m})\end{array}$ & $\begin{array}{c}\text { Organic } \\
\text { matter } \\
(\%)\end{array}$ & $\begin{array}{c}\text { Available } \\
\mathbf{N} \\
\text { (ppm) }\end{array}$ & $\begin{array}{c}\text { Available } \\
\text { P } \\
\text { (ppm) }\end{array}$ & $\begin{array}{c}\text { Available } \\
\text { K } \\
(\mathrm{ppm})\end{array}$ \\
\hline $2014 / 15$ & 8.20 & 2.05 & 1.21 & 17.75 & 10.65 & 158.50 \\
\hline $2015 / 16$ & 8.13 & 2.90 & 1.55 & 19.25 & 12.45 & 204.00 \\
\hline
\end{tabular}

The experimental design was split-split-plot with three replicates. The irrigation regimes were allocated to the main plots, the nitrogen rate to the sub-plots, and the potassium rate to the sub-sub plots. The sub-sub plot size was $20 \mathrm{~m}^{2}$ (4 X $5 \mathrm{~m}$ ). To avoid the influence of lateral movement of irrigation water, the major plots were separated by $1.5 \mathrm{~m}$ wide levees. Wheat seed was drilled by hand in rows $20 \mathrm{~cm}$ a part at the rate of $50 \mathrm{~kg}$ seed feddan $^{-1}$ on 15 and 18 November in 2014 and 2015 seasons, respectively. Each sub-sub plot included 20 rows. The standard cultural practices for cultivating wheat were followed exactly as recommended. Table 3 displays the weather data from Sakha Station over the two growing seasons.

Table 3. Mean monthly of temperature, relative humidity, wind speed and pan evaporation as well as rainfall quantity in 2014/2015 and 2015/2016 seasons.

\begin{tabular}{|c|c|c|c|c|c|c|c|c|c|c|}
\hline \multirow[t]{2}{*}{ Month } & \multicolumn{2}{|c|}{$\begin{array}{c}\text { Temperature } \\
\left({ }^{\circ} \mathrm{C}\right)\end{array}$} & \multicolumn{2}{|c|}{$\begin{array}{c}\text { Relative humidity } \\
(\%)\end{array}$} & \multicolumn{2}{|c|}{$\begin{array}{c}\text { Wind speed } \\
\text { (km/day) }\end{array}$} & \multicolumn{2}{|c|}{$\begin{array}{c}\text { Pan evaporation } \\
(\mathrm{mm} / \text { month })\end{array}$} & \multicolumn{2}{|c|}{$\begin{array}{c}\text { Rainfall } \\
(\mathrm{mm} / \mathrm{month})\end{array}$} \\
\hline & $2015 / 16$ & $2014 / 15$ & $2015 / 16$ & $2014 / 15$ & $2015 / 16$ & $2014 / 15$ & $2015 / 16$ & $2014 / 15$ & $2015 / 16$ & $2014 / 15$ \\
\hline Nov & 19.05 & 19.41 & 74.15 & 75.6 & 67.3 & 70.3 & 277 & 319 & 24.6 & 52.40 \\
\hline Dec & 15.99 & 14.03 & 76.05 & 77.9 & 46.03 & 57.9 & 172 & 250 & 5.70 & 25.00 \\
\hline Jan & 12.63 & 12.38 & 74.6 & 74.05 & 70.8 & 69.2 & 271 & 252 & 52.55 & 43.21 \\
\hline Feb & 13.35 & 15.97 & 74.75 & 69.05 & 72.91 & 58.8 & 290 & 252 & 38.80 & - \\
\hline Mar & 17.19 & 18.05 & 70.59 & 69.90 & 87.64 & 63.2 & 323 & 359 & 6.25 & 13.2 \\
\hline Apr & 18.17 & 24.33 & 63.4 & 61.70 & 95.7 & 87.1 & 607 & 594 & 23.90 & - \\
\hline May & 24.49 & 26.6 & 61.7 & 58.40 & 114.6 & 97 & 715 & 647 & - & - \\
\hline
\end{tabular}

At harvest, number of spikes $\mathrm{m}^{-2}$ was counted. Ten spikes were collected randomly to estimate number of grains / spike, and 1000-grain weight. The central area of $8 \mathrm{~m}^{2}(2 \mathrm{X}$ $4 \mathrm{~m}$ ) were harvested and threshed to calculate grain and straw yield. The weight of grain yield was adjusted to $14.5 \%$ moisture content.

\section{Water relations:}

A rectangular sharp crested weir was used to measure the amount of irrigation water. Soil samples were collected at $15 \mathrm{~cm}$ depths up to $60 \mathrm{~cm}$ before and after irrigation to determine the water consumptive use (WCU) of the wheat plant according to Israelsen and Hansen (1962) equation as follows:

$$
\mathrm{WCU}=\frac{\theta_{2}-\theta_{1}}{100} \times \text { B.d } \times \mathrm{D} \times 4200
$$

\section{Where:}

WCU = Amount of water consumptive use ( $\mathrm{m}^{3} /$ feddan). $\theta_{2}=$ Soil moisture content $\%$ after irrigation. $\theta_{1}=$ Soil moisture content $\%$ before the next irrigation. B.d = Bulk density $\left(\mathrm{g} / \mathrm{cm}^{3}\right)$.

D = Depth of soil layer $(\mathbf{m})$.

Water consumptive use (WCU) was computed from sowing to harvest. Water productivity was calculated as the ratio of grain and straw yields with amount of applied irrigation water (PAW) and water consumptive use (PWCU) according to Michael (1978)as follows:

$$
\text { PWA }=\frac{\text { Yield }(\mathrm{kg} / \text { feddan })}{\text { Applied water }\left(m^{3} / \text { feddan }\right)}
$$

$$
\text { PWCU }=\frac{\text { Yield }(\mathrm{kg} / \text { feddan })}{\text { water consumpitive use }\left(m^{3} / \text { feddan }\right)}
$$


According to Gomez \& Gomez (1984), the collected data were analyzed using analysis of variance Duncan's Multiple Range Test was used to compare treatment means (Duncan, 1955). All statistical analyses were carried out using the analysis of variance technique and the "MSTATC" computer software package.

\section{RESULTS AND DISCUSSION}

\section{A. Yield attributes:}

Spikes number $\mathrm{m}^{-2}$, grains number spike ${ }^{-1}$ and 1000grain weight as affected by irrigation regime, nitrogen rate and potassium rate in 2015 and 2016 seasons are presented in Table 4. Irrigation regime had significant effect on spikes number $\mathrm{m}^{-2}$, grains number spike $\mathrm{s}^{-1}$ and 1000 -grain weight in both seasons. Irrigation at 40 and $55 \%$ depletion of available soil moisture DASM resulted in significant increase in spikes number $\mathrm{m}^{-2}$, grains number spike ${ }^{-1}$ and 1000 -grain weight compared with irrigation at $70 \%$ DASM. There were no significant differences in these traits between irrigation at 40 and 55\% DASM in both seasons. Water stress (irrigation at $70 \%$ DASM) accelerated tiller death which causes reduction in number of survival active tillers (spikes number $\mathrm{m}^{-2}$ ). Certainly the sufficient soil moisture content induced vegetative growth (cell division and elongation) and thus the expansion of leaves, which resulted in great photosynthetic available for dry matter accumulation and in turn increased spike number and grain number per spike. In this regard, Mekkei and El Haggan (2014) concluded that applying five irrigations at various wheat growth phases resulted in a larger number of spikes $\mathrm{m}^{-2}$, whereas omitting irrigation at stem elongation, booting, or anthesis stage resulted in a lower number of spikes $\mathrm{m}^{-2}$. These findings are consistent with those of Attia and Barsoum (2013), Rizk and Sherif (2014), Shirazi et al. (2014), and Gharib and Meleha (2016).

Table 4. Grain yield attributes, straw yield and harvest index as affected by irrigation regime, nitrogen and potassium rate in 2014/15 and 2015/16 season

\begin{tabular}{|c|c|c|c|c|c|c|c|c|c|c|}
\hline \multirow[t]{2}{*}{ Factor } & \multicolumn{2}{|c|}{$\begin{array}{c}\text { Spikes } \\
\left(\mathbf{N o} / \mathbf{m}^{2}\right)\end{array}$} & \multicolumn{2}{|c|}{$\begin{array}{c}\text { Grains } \\
\text { (No/spike) }\end{array}$} & \multicolumn{2}{|c|}{$\begin{array}{c}1000-\mathrm{g} \\
(\mathrm{g})\end{array}$} & \multicolumn{2}{|c|}{$\begin{array}{c}\text { Straw } \\
\text { yield(t/fed) }\end{array}$} & \multicolumn{2}{|c|}{$\begin{array}{c}\text { Harvest } \\
\text { index }\end{array}$} \\
\hline & $2014 / 15$ & $2015 / 16$ & $2014 / 15$ & $2015 / 16$ & $2014 / 15$ & $2015 / 16$ & $2014 / 15$ & $2015 / 16$ & $2014 / 15$ & $2015 / 16$ \\
\hline Depletion \% (D) & & & & & & & & & & \\
\hline 40 & $340 \mathrm{a}$ & $355 \mathrm{a}$ & $61.2 \mathrm{a}$ & $62.1 \mathrm{a}$ & $52.65 \mathrm{a}$ & $50.16 \mathrm{a}$ & $4.683 \mathrm{a}$ & $4.146 \mathrm{a}$ & 0.389 & 0.421 \\
\hline 55 & $334 \mathrm{a}$ & $340 \mathrm{a}$ & $60.4 \mathrm{a}$ & $58.9 \mathrm{a}$ & $50.59 \mathrm{~b}$ & $49.19 \mathrm{ab}$ & $4.550 \mathrm{a}$ & $3.698 \mathrm{ab}$ & 0.383 & 0.417 \\
\hline 70 & $311 \mathrm{~b}$ & $299 \mathrm{~b}$ & $55.3 \mathrm{~b}$ & $54.8 \mathrm{~b}$ & $45.00 \mathrm{c}$ & $48.38 \mathrm{~b}$ & $3.171 \mathrm{~b}$ & $3.124 \mathrm{~b}$ & 0.389 & 0.404 \\
\hline F test & ** & ** & $* *$ & ** & & * & ** & * & $\mathrm{Ns}$ & Ns \\
\hline kg N/fed. (N) & & & & & & & & & & \\
\hline 50 & 307c & $309 b$ & $55.7 \mathrm{~b}$ & $54.4 \mathrm{~b}$ & $44.70 \mathrm{c}$ & $48.38 c$ & $3.723 \mathrm{~b}$ & $3.044 \mathrm{~b}$ & 0.389 & 0.418 \\
\hline 70 & $331 b$ & $332 \mathrm{ab}$ & $59.0 \mathrm{a}$ & $58.4 \mathrm{ab}$ & $53.35 a$ & $50.22 \mathrm{a}$ & $4.206 \mathrm{ab}$ & $3.730 \mathrm{a}$ & 0.388 & 0.417 \\
\hline 90 & $346 a$ & $353 a$ & $62.2 \mathrm{a}$ & $63.0 \mathrm{a}$ & $50.18 \mathrm{~b}$ & $49.13 \mathrm{~b}$ & $4.475 \mathrm{a}$ & $4.195 \mathrm{a}$ & 0.385 & 0.408 \\
\hline F test & $* *$ & * & $* *$ & $* *$ & & $*$ & ** & $*$ & $\mathrm{Ns}$ & Ns \\
\hline kg K $20 / f e d .(K)$ & & & & & & & & & & \\
\hline 0 & $306 c$ & $295 c$ & $55.1 \mathrm{c}$ & $55.3 \mathrm{c}$ & $46.01 \mathrm{c}$ & $48.15 c$ & 4.022 & 3.535 & 0.383 & 0.41 \\
\hline 12 & $332 b$ & $334 b$ & $59.1 \mathrm{~b}$ & $58.2 \mathrm{~b}$ & $50.05 \mathrm{~b}$ & $49.38 \mathrm{~b}$ & 4.138 & 3.691 & 0.387 & 0.416 \\
\hline 24 & $345 a$ & $365 a$ & $62.7 a$ & $62.3 \mathrm{a}$ & $52.17 \mathrm{a}$ & $50.21 \mathrm{a}$ & 4.244 & 3.743 & 0.391 & 0.416 \\
\hline F test & ** & ** & $* *$ & ** & * & * & Ns & Ns & Ns & Ns \\
\hline Interaction & & & & & & & & & & \\
\hline $\mathrm{D} \times \mathrm{N}$ & $* *$ & $* *$ & $* *$ & $* *$ & $* *$ & $* *$ & $* *$ & $* *$ & Ns & Ns \\
\hline $\mathrm{D} \times \mathrm{K}$ & $* *$ & $* *$ & $* *$ & $* *$ & $* *$ & NS & $* *$ & $* *$ & Ns & Ns \\
\hline $\mathrm{N} \times \mathrm{K}$ & $* *$ & $* *$ & $* *$ & $* *$ & $* *$ & $* *$ & $* *$ & $* *$ & Ns & Ns \\
\hline $\mathrm{D} \times \mathrm{N} \times \mathrm{K}$ & $* *$ & $* *$ & $* *$ & $* *$ & $* *$ & $* *$ & $* *$ & $* *$ & Ns & Ns \\
\hline
\end{tabular}

$*, * *$ and Ns indicate $\mathrm{p}<0.05,<0.01$ and not significant, respectively. Means of each factor followed by the same letter are not significantly different at $5 \%$ level, according to Duncan s multiple range test.

In all seasons, increasing the nitrogen rate from 50 to $90 \mathrm{~kg} \mathrm{~N} \mathrm{ha}^{-1}$ steadily increased the number of spikes $\mathrm{m}^{-2}$ and the amount of grains spike ${ }^{-1}$. In the two seasons, the rates of 70 and $90 \mathrm{~kg} \mathrm{~N} \mathrm{fed}^{-1}$ were statistically equal in the two features described. Nitrogen's effect may be linked mostly to its role in the stimulation of numerous physiological processes such as cell division and cell elongation, which resulted in more photosynthetic area, which boosted photosynthetic production and, as a result, spike and grain numbers. In all seasons, the application of $70 \mathrm{~kg} \mathrm{~N}$ fed $^{-1}$ enhanced 1000-grain weight much more than the low rate of $50 \mathrm{~kg} \mathrm{~N}$ and the high rate of $90 \mathrm{~kg} \mathrm{~N}$ fed $^{-1}$. The reduction in 1000-grain weight at high $\mathrm{N}$ rate may be due to increase nitrogen content in plant, which may be resulted in a shortage of carbohydrate supplied per grain and in turne it is directly caused by an excessive number of grains produced by high $\mathrm{N}$ fertilization. The promoting effects of nitrogen on spikes number $\mathrm{m}^{-2}$ and grains number spike ${ }^{-1}$ was reported by El-Sayed and Hammad (2007), El-Samahy (2009), Ali (2013) and Javaid et al. (2014). El-Samahy (2009) added that increasing nitrogen fertilizer decreased 1000 kernel-weight.
Each increase in potassium fertilizer raised spikes number $/ \mathrm{m}^{2}$, grains number/ spike, and 1000-grain weight significantly during the two seasons. $\mathrm{K}$ application increased enzymatic activities, which likely resulted in higher nutrient mobilization in soil and plant, as well as photosynthetic translocation in plant, resulting in more spikes $\mathrm{m}^{-2}$, grains spike $^{-1}$, and 1000-grain weight. These findings are corroborated by prior studies by El-Ashry and El-Kholy (2005), as well as Gharib and Meleha (2016).

All interactions had significant effect on spikes number $\mathrm{m}^{-2}$, grains number spike $\mathrm{e}^{-1}$ and 1000 -grain weight in both seasons and except the interaction irrigation and potassium for 1000-grain weight in the second season (Table 4).

\section{B. Straw and grain yields and harvest index:}

Means of straw yield, grain yield and harvest index as affected by irrigation regime, nitrogen and potassium rate in 2015 and 2016 seasons are given in Tables 4 and 5.

Irrigation regime had significant effect on straw and grain yields in the two seasons. However, harvest index was not affected by irrigation regime in both seasons. Straw and grain yields per feddan were significantly increased by 
increasing soil moisture in root zone by irrigation at $40 \%$ DASM compared with irrigation at 70\% DASM. Wheat plots irrigated at 40 or $55 \%$ DASM produced nearly identical straw and grain yields. Soil moisture abundance increased grain yield by increasing the number of spikes $\mathrm{m}^{-2}$, grains $\mathrm{spike}^{-1}$, and grain weight. The increase in straw yield could be attributed to an increase in the number of tillers per unit area. Adequate water during or after anthesis not only helped the wheat plant to improve photosynthetic rate, but also provided extra time for the carbohydrates in grains to translocate, resulting in larger grain size and, eventually, increased grain output (Mirbahar et al., 2009). These findings are consistent with those obtained by Rizk and sherif (2014), Shirazi et al (2014) and Gharib and Meleha (2016).
There was a substantial difference in grain and straw yields obtained among nitrogen rates in both seasons. Raising the nitrogen rate from 50 to $90 \mathrm{~kg} \mathrm{~N} / \mathrm{fed}$. resulted in a considerable improvement in grain and straw yields. In the two seasons, grain and straw yields were statistically equivalent at rates of 70 and $90 \mathrm{~kg} \mathrm{~N} / \mathrm{fed}$. Thus, the increased nitrogen rate (90 $\mathrm{kg} \mathrm{N} / \mathrm{fed}$ ) improved grain yield by increasing the number of spikes $\mathrm{m}^{-2}$ and grains spike ${ }^{-1}$, and the medium nitrogen rate ( $70 \mathrm{~kg} \mathrm{~N} / \mathrm{fed}$ ) increased grain yield by increasing the previous two traits as well as the 1000-grain weight. These findings corroborate those of El-Sayed and Hammad (2007), Hafez (2007), EL-Samahy (2009),Zeidan $e t$ al. (2009), Abedi et al. (2011), El-Hag (2011) and EL-Hag (2012).

Table 5. Grain yield as affected by interaction of irrigation regime, nitrogen and potassium rate in 2014/15 and 2015/16

\begin{tabular}{|c|c|c|c|c|c|c|c|c|c|}
\hline \multirow{4}{*}{ D \% } & \multirow{4}{*}{$\begin{array}{c}\mathbf{K g} \\
\mathbf{K}_{2} \mathrm{Ofed}^{-1}\end{array}$} & \multicolumn{4}{|c|}{ 2014/2015 season } & \multicolumn{4}{|c|}{ 2015/2016 season } \\
\hline & & \multicolumn{3}{|c|}{$\mathrm{Kg} \mathrm{N}_{\mathrm{fed}}{ }^{-1}$} & \multirow{2}{*}{ Mean } & \multicolumn{3}{|c|}{$\mathrm{Kg} \mathrm{N}_{\mathrm{Ned}}{ }^{-1}$} & \multirow{2}{*}{ Mean } \\
\hline & & 50 & 70 & 90 & & 50 & 70 & 90 & \\
\hline & & \multicolumn{3}{|c|}{ Dx N-mean } & D-mean & \multicolumn{3}{|c|}{ Dx N-mean } & D-mean \\
\hline 40 & & $2.292 \mathrm{~b}$ & $3.085 \mathrm{a}$ & $3.220 \mathrm{a}$ & $2.865 \mathrm{a}$ & $2.359 \mathrm{~b}$ & $3.119 \mathrm{a}$ & $3.176 \mathrm{a}$ & $2.885 \mathrm{a}$ \\
\hline 55 & & $2.108 \mathrm{~b}$ & $3.031 \mathrm{a}$ & $3.193 \mathrm{a}$ & $2.777 \mathrm{a}$ & $2.194 \mathrm{~b}$ & $3.086 \mathrm{a}$ & $3.130 \mathrm{a}$ & $2.803 a b$ \\
\hline \multirow[t]{6}{*}{70} & & $1.828 \mathrm{~b}$ & $2.028 \mathrm{~b}$ & $2.257 \mathrm{~b}$ & $2.038 \mathrm{~b}$ & $1.982 \mathrm{~b}$ & $2.360 \mathrm{~b}$ & $2.395 \mathrm{~b}$ & $2.246 \mathrm{~b}$ \\
\hline & & & $\mathrm{N} \times \mathrm{K}$-mean & & K-mean & & $\mathrm{N} \times \mathrm{K}$-mear & & K-mean \\
\hline & 0 & $1.978 \mathrm{c}$ & $2.548 a b c$ & $2.789 \mathrm{ab}$ & $2.438 \mathrm{~b}$ & $2.087 \mathrm{~b}$ & $2.735 \mathrm{a}$ & $2.757 \mathrm{a}$ & $2.527 \mathrm{~b}$ \\
\hline & 12 & $2.068 \mathrm{c}$ & $2.727 \mathrm{ab}$ & $2.932 \mathrm{a}$ & $2.576 \mathrm{ab}$ & $2.181 \mathrm{~b}$ & $2.874 \mathrm{a}$ & $2.929 \mathrm{a}$ & $2.661 \mathrm{ab}$ \\
\hline & 24 & $2.182 \mathrm{bc}$ & $2.869 \mathrm{a}$ & $2.949 \mathrm{a}$ & $2.667 \mathrm{a}$ & $2.267 \mathrm{~b}$ & $2.956 \mathrm{a}$ & $3.015 \mathrm{a}$ & $2.746 \mathrm{a}$ \\
\hline & & \multicolumn{3}{|c|}{ D x N x K-mean } & DxK-mean & \multicolumn{3}{|c|}{ D x N x K-mean } & DxK-mean \\
\hline \multirow[t]{3}{*}{40} & 0 & $2.127 \mathrm{ef}$ & $2.963 \mathrm{a}-\mathrm{d}$ & $3.138 \mathrm{ab}$ & $2.743 \mathrm{a}$ & $2.219 \mathrm{ef}$ & $3.029 \mathrm{a}-\mathrm{d}$ & $3.070 \mathrm{a}-\mathrm{d}$ & $2.773 \mathrm{ab}$ \\
\hline & 12 & $2.271 \mathrm{c}-\mathrm{f}$ & $3.074 \mathrm{abc}$ & $3.268 \mathrm{a}$ & $2.871 \mathrm{a}$ & $2.368 \mathrm{ef}$ & $3.139 \mathrm{ab}$ & $3.206 \mathrm{ab}$ & $2.904 \mathrm{a}$ \\
\hline & 24 & $2.477 \mathrm{a}-\mathrm{f}$ & $3.218 \mathrm{a}$ & $3.253 \mathrm{a}$ & $2.983 \mathrm{a}$ & $2.488 \mathrm{def}$ & $3.190 \mathrm{ab}$ & $3.252 \mathrm{a}$ & $2.977 \mathrm{a}$ \\
\hline \multirow[t]{3}{*}{55} & 0 & $2.023 \mathrm{f}$ & 2.869 a-e & $3.115 \mathrm{ab}$ & $2.669 \mathrm{ab}$ & $2.106 \mathrm{ef}$ & $2.996 \mathrm{a}-\mathrm{d}$ & $3.002 \mathrm{a}-\mathrm{d}$ & $2.701 \mathrm{ab}$ \\
\hline & 12 & $2.106 \mathrm{ef}$ & $3.059 \mathrm{abc}$ & $3.225 \mathrm{a}$ & $2.797 \mathrm{a}$ & $2.193 \mathrm{ef}$ & $3.099 \mathrm{abc}$ & $3.182 \mathrm{ab}$ & $2.824 \mathrm{a}$ \\
\hline & 24 & $2.196 \mathrm{def}$ & $3.165 \mathrm{ab}$ & $3.239 \mathrm{a}$ & $2.867 \mathrm{a}$ & $2.284 \mathrm{ef}$ & $3.161 \mathrm{ab}$ & $3.205 \mathrm{ab}$ & $2.884 \mathrm{a}$ \\
\hline \multirow[t]{3}{*}{70} & 0 & $1.783 \mathrm{f}$ & $1.813 \mathrm{f}$ & $2.113 \mathrm{ef}$ & $1.903 \mathrm{c}$ & $1.937 \mathrm{f}$ & $2.181 \mathrm{ef}$ & $2.200 \mathrm{ef}$ & $2.106 \mathrm{c}$ \\
\hline & 12 & $1.827 \mathrm{f}$ & $2.047 \mathrm{ef}$ & $2.303 \mathrm{c}-\mathrm{f}$ & $2.059 \mathrm{c}$ & $1.981 \mathrm{ef}$ & $2.384 \mathrm{ef}$ & $2.398 \mathrm{ef}$ & $2.254 \mathrm{c}$ \\
\hline & 24 & $1.873 \mathrm{f}$ & $2.223 \mathrm{def}$ & $2.356 \mathrm{~b}-\mathrm{f}$ & $2.151 \mathrm{bc}$ & $2.028 \mathrm{ef}$ & $2.516 \mathrm{c}-\mathrm{f}$ & $2.586 \mathrm{~b}-\mathrm{e}$ & $2.377 \mathrm{bc}$ \\
\hline $\mathrm{N}$-me & & $2.076 \mathrm{~b}$ & $2.715 \mathrm{a}$ & $2.890 \mathrm{a}$ & & $2.178 \mathrm{~b}$ & $2.855 \mathrm{a}$ & $2.900 \mathrm{a}$ & \\
\hline
\end{tabular}

Means of each factor followed by the same letter are not significantly different at $5 \%$ level, according to Duncan $s$ multiple range test.

Potassium fertilizer significantly affected grain yield in both seasons and harvest index in the first season, only. Application of $24 \mathrm{~kg} \mathrm{KO}_{2}$ feddan ${ }^{-1}$ significantly increased the mentioned traits compared the control treatment without potassium. There was no significant deference in these respects between rates of 24 and $\mathrm{kg} \mathrm{KO}_{2}$ feddan ${ }^{-1}$. Application of potassium fertilizer increased grain yield through increased spikes number $\mathrm{m}^{-2}$, grains number spike ${ }^{-1}$ and 1000-grain weight. The increase in harvest index is due to increase in grain yield as reported by Gharib and Meleha (2016).

All the first and second order of interactions exerted a significant effect on straw yield and grain yield in the two seasons (Table 4). None of the interaction had a significant effect on harvest index in the two seasons. Data in Table 5 show that irrigation at 40 or $55 \%$ DASM along with addition of 70 or $90 \mathrm{~kg} \mathrm{~N} \mathrm{fed}^{-1}$, being insignificant, outyielded the other combination among irrigation regime and nitrogen rate in grain yield in both seasons. The interaction between irrigation regime and potassium rate had a significant effect on grain yield (Table 5). No significant difference in grain yield among the three potassium rates with irrigation at 40 or $55 \%$ DASM. The mention interactions resulted in significant increase in grain yield compared with irrigation at $70 \%$ DASM without potassium or $12 \mathrm{~kg} \mathrm{k}_{2} \mathrm{O}$ fed $^{-1}$. The interaction of the medium irrigation regime without potassium did not differ than the low irrigation regime with $24 \mathrm{~kg} \mathrm{k}_{2} \mathrm{O}$ fed $^{-1}$ in grain yield. This indicated that application of potassium improved grain yield at water stress. Data also indicated that grain yield was more affected by irrigation regime than potassium fertilizer. El-Ashry and El-Kholy (2005) found that spraying wheat plants with $\mathrm{K}$ before submitting them to drought treatment reduces the detrimental effects of drought on growth and, as a result, enhances yield per plant. Zareian et al. (2014) concluded that maximum grain yield values could be obtained from wheat cultivar WS-82-9 when irrigated normally and sprayed with 3.0 percent $\mathrm{K} 2 \mathrm{O}$. These conclusions are backed by earlier research findings. Aown et al (2012) and Gharib and Meleha (2016).

Grain yield was significantly affected by the interaction of nitrogen rate $\mathrm{x}$ potassium rate in both seasons (Table 5). The addition of 70 or $90 \mathrm{~kg} \mathrm{~N}$ fed-1 potassium fertilizer had no influence on grain output. In grain yield, the aforementioned interactions outperformed $50 \mathrm{~kg} \mathrm{~N}^{-1}$ without potassium and $12 \mathrm{~kg} \mathrm{k} 2 \mathrm{O}$ fed $^{-1}$. In both seasons, the second-order interaction had a considerable impact on grain yield (Table 5). In both seasons, the relative ranking of the interaction between irrigation regime, nitrogen rate, and potassium rate for grain output was inconclusive. (Table 5). The relative ranking of the interaction among irrigation regime, nitrogen rate and potassium rate for grain yield was 
inconsistent in both seasons. Irrigation at 40 or 55\% DASM along with addition of 70 or $90 \mathrm{~kg} \mathrm{~N} \mathrm{fed}^{-1}$ at any potassium rate were among those treatments having high grain yield, being insignificant, in both seasons. The interaction of low irrigation regime $\mathrm{x}$ low nitrogen rat $\mathrm{x}$ without potassium was recorded the lowest grain yield in the two seasons.

\section{Water measurements:}

\section{Seasonal water}

Seasonal of applied irrigation water (AW), water consumptive use (WCU) and stored water (SW) from sowing to harvest as affected by irrigation regimes, nitrogen and potassium rate in 2015 and 2016 seasons are presented in Table 6. AW, WCU and SW were gradually decreased by increasing soil moisture depletion from $40 \%$ to $70 \%$ DASM before irrigation in both seasons. Such increase in seasonal irrigation water (AW) by decreasing soil moisture depletion at irrigation may be attributed to increase in available moisture in root zone, which resulted in considerable increase in leaf area, in turn resulted in a greater transpiration and water requirement.

Meleha (2016) reported that the seasonal values of water applied can be descended in order irrigation to reach the field capacity in soil depths $0-60 \mathrm{~cm}>0-40 \mathrm{~cm}>0-20 \mathrm{~cm}$.Jazy et al (2012) reported that wheat may be irrigated after $90 \mathrm{~mm}$ cumulative pan evaporation not only may save about $22 \%$ in irrigation water with no significant loss in yield under condition similar to this experiment.
The increase of actual water consumptive use at full irrigation treatment (W1, 5I-D60) can be attributed to the increase in evaporation at high available moisture; more supplying plants with sufficient moisture led to an increase in green cover and hence increase transpiration. Rizk and sherif (2014) reported that consumptive use was increased with increasing available soil moisture. Shirazi et al (2014) found that water consumed by wheat genotypes throughout the growing season was about $293 \mathrm{~mm} / \mathrm{m}^{2}$ under control conditions. Tari (2016) reported that the seasonal waterconsumptive use of experimental treatments varied between 206 and $571 \mathrm{~mm}$. These results agree with those of Meleha (2016).

Each increment of nitrogen fertilizer increased AW, WCU and SW in the two seasons. Such effect of nitrogen could be attributed mainly to its role in the stimulation of various physiological processes including cell division and cell elongation of internodes resulting in more tillers formation, leaf numbers and leaf area, which resulted in more evapotranspiration (WCU) and in turn increased water requirement (AW). Jacobet al (2014) reported that Applying sufficient $\mathrm{N}$ fertilizer pre plant is most beneficial to WUE.

Application of potassium fertilizer resulted in slight increase in AW, WCU and SW in compared with control (without k) in the two seasons. These results are supported by the previous findings of Gharib and Meleha (2016).

Table 6. Water Applied (WA), Productivity of Water Applied (PWA), Water Consumptive Use (WCU), Productivity of Water Consumptive Use (PWCU), Stored Water (SW) And Water Application Efficiency (WAE) as affected by irrigation regime, nitrogen rate and potassium rate in 2014/15 and 2015/16season

\begin{tabular}{|c|c|c|c|c|c|c|c|c|}
\hline Factor & $\begin{array}{c}\text { WA } \\
\left(\mathbf{m}^{3} / \mathbf{f e d}\right)\end{array}$ & $\begin{array}{c}\text { PWA } \\
(\mathrm{kg} \text { grain//m³) }\end{array}$ & $\begin{array}{c}\text { PWA } \\
(\text { kg straw/m³) }\end{array}$ & $\begin{array}{c}\text { WCU } \\
\text { (m3/fed) }\end{array}$ & $\begin{array}{c}\text { PWCU } \\
(\text { kg grain/m³) }\end{array}$ & $\begin{array}{c}\text { PWCU } \\
\left(\mathrm{kg} \mathrm{straw} / \mathbf{m}^{3}\right)\end{array}$ & $\begin{array}{c}\mathbf{S W} \\
\left(\mathbf{m}^{3} / \mathbf{f e d}\right)\end{array}$ & $\begin{array}{c}\text { WAE } \\
(\%)\end{array}$ \\
\hline & \multicolumn{8}{|c|}{$2014 / 2015$ season } \\
\hline Depletion \% (D) & & & & & & & & \\
\hline 40 & 3190 & 0.90 & 1.47 & 1973 & 1.45 & 2.37 & 2440 & 76.45 \\
\hline 55 & 2824 & 0.98 & 1.61 & 1694 & 1.64 & 2.68 & 2215 & 78.39 \\
\hline 70 & 2476 & 0.82 & 1.28 & 1375 & 1.48 & 2.30 & 2062 & 83.24 \\
\hline \multicolumn{9}{|l|}{ kg N/fed. (N) } \\
\hline 50 & 2767 & 0.75 & 1.34 & 1647 & 1.27 & 2.26 & 2085 & 75.73 \\
\hline 70 & 2831 & 0.95 & 1.47 & 1678 & 1.61 & 2.49 & 2241 & 79.44 \\
\hline 90 & 2892 & 0.99 & 1.54 & 1717 & 1.68 & 2.60 & 2391 & 82.90 \\
\hline \multicolumn{9}{|l|}{ kg K $2 \mathrm{O} /$ fed. (K) } \\
\hline 0 & 2817 & 0.86 & 1.42 & 1676 & 1.45 & 2.39 & 2234 & 79.55 \\
\hline 12 & 2833 & 0.90 & 1.45 & 1681 & 1.53 & 2.45 & 2240 & 79.32 \\
\hline 24 & 2840 & 0.93 & 1.49 & 1684 & 1.58 & 2.51 & 2243 & 79.20 \\
\hline & \multicolumn{8}{|c|}{ 2015/2016 season } \\
\hline Depletion \% (D) & & & & & & & & \\
\hline $\begin{array}{l}40 \\
55\end{array}$ & $\begin{array}{l}3204 \\
2884\end{array}$ & $\begin{array}{l}0.90 \\
0.97\end{array}$ & $\begin{array}{l}1.29 \\
1.28\end{array}$ & 1979 & $\begin{array}{l}1.46 \\
1.63\end{array}$ & $\begin{array}{l}2.09 \\
2.15\end{array}$ & $\begin{array}{l}2472.4 \\
2266.9\end{array}$ & $\begin{array}{c}77.1 \\
78.51\end{array}$ \\
\hline 70 & 2500 & 0.90 & 1.25 & 1383 & 1.62 & 2.25 & 2095.3 & 83.76 \\
\hline \multicolumn{9}{|l|}{ kg N/fed. (N) } \\
\hline 50 & 2784 & 0.79 & 1.09 & 1653 & 1.33 & 1.84 & 2097.7 & 75.74 \\
\hline 70 & 2864 & 1.00 & 1.30 & 1698 & 1.69 & 2.19 & 2278.3 & 79.84 \\
\hline 90 & 2941 & 0.98 & 1.43 & 1723 & 1.69 & 2.46 & 2458.4 & 83.78 \\
\hline \multicolumn{9}{|l|}{$\mathrm{kg} \mathrm{K}_{2} \mathrm{O} / \mathrm{fed} .(\mathrm{K})$} \\
\hline 0 & 2852 & 0.88 & 1.23 & 1688 & 1.50 & 2.10 & 2273.3 & 79.92 \\
\hline 12 & 2866 & 0.93 & 1.28 & 1692 & 1.58 & 2.19 & 2278.8 & 79.72 \\
\hline 24 & 2871 & 0.96 & 1.30 & 1694 & 1.63 & 2.22 & 2282.4 & 79.72 \\
\hline
\end{tabular}

Water Applied (WA), Productivity of Water Applied (PWA), Water Consumptive Use (WCU), Productivity of Water Consumptive Use (PWCU), Stored Water (SW) and Water Application Efficiency (WAE)

There were substantial differences in AW, WCU and SW among combination of irrigation regime and nitrogen fertilizer rate in both seasons (Tables 7 and 8). AW, WCU and SW were increased by decreasing water depletion before irrigation along with increasing nitrogen rate. At the same nitrogen rate, decreasing water depletion before irrigation led to markedly increase in AW, WCU and SW in the two seasons. Data showed that irrigation regime had more effect on the mentioned trait than nitrogen rate. The interaction of irrigation at $40 \%$ DASM and $90 \mathrm{~kg} \mathrm{~N}^{-1} \mathrm{fed}^{-1}$ recorded the highest values of AW (3241 and $\left.3256 \mathrm{~m}^{3} \mathrm{fed}^{-1}\right)$, WCU (2011 and $2017 \mathrm{~m}^{3} \mathrm{fed}^{-1}$ ) and SW (2618 and $2688 \mathrm{~m}^{3} \mathrm{fed}^{-1}$ ), while irrigation at $70 \%$ 
DASM with $50 \mathrm{~kg} \mathrm{~N}$ fed $^{-1}$ recorded the lowest values of AW (2421 and $2433 \mathrm{~m}^{3} \mathrm{fed}^{-1}$ ), WCU (1342 and $1350 \mathrm{~m}^{3} \mathrm{fed}^{-1}$ ) and SW (1943 and $1961 \mathrm{~m}^{3} \mathrm{fed}^{-1}$ ) in the two season.

The interaction between irrigation and $\mathrm{K}$ fertilizer distinctly influenced v,AW, WCU and SW in both seasons. Application of $\mathrm{K}$ fertilizer slightly increased the mentioned traits at the same irrigation regime in the two seasons. Data show that irrigation treatments were more effective on AW, WCU and SW than K fertilizer.

Data in Tables 7 and 8 shows that the interaction between $\mathrm{N}$ and $\mathrm{K}$ rates nitrogen rate more influenced on $\mathrm{AW}$, WCU and SW than K rate. These traits were increased by increasing $\mathrm{N}$ rate at any $\mathrm{K}$ rate, while it was slightly increased by $\mathrm{K}$ fertilizer compared without $\mathrm{K}$ at any $\mathrm{N}$ rate.

Table 7. Water Applied (WA), Productivity of Water Applied (PWA), Water Consumptive Use (WCU), Productivity of Water Consumptive Use (PWCU), Stored Water (SW) And Water Application Efficiency (WAE) as affected by irrigation regime (depletion \%,D), nitrogen and potassium rates in 2014/2015 season.

\begin{tabular}{|c|c|c|c|c|c|c|c|c|c|c|}
\hline D & $\mathbf{N}$ & $\mathbf{K}$ & $\begin{array}{c}\text { WA } \\
\left(\mathbf{m}^{3} / \text { fed }\right)\end{array}$ & $\begin{array}{c}\text { PWA } \\
(\mathrm{kg} \text { grain/m³) }\end{array}$ & $\begin{array}{c}\text { PWA } \\
\left(\mathrm{kg} \mathrm{straw} / \mathbf{m}^{3}\right)\end{array}$ & $\begin{array}{l}\text { WCU } \\
\text { (m3/fed) }\end{array}$ & $\begin{array}{c}\text { PWCU } \\
(\mathrm{kg} \text { grain/m/3) }\end{array}$ & 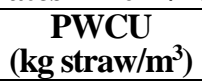 & $\begin{array}{c}\mathbf{S W} \\
\left(\mathbf{m}^{3} / \mathbf{f e d}\right)\end{array}$ & $\begin{array}{l}\text { WAE } \\
(\%)\end{array}$ \\
\hline 1 & 1 & 1 & 3124 & 0.68 & 1.31 & 1933 & 1.10 & 2.12 & 2252 & 72.09 \\
\hline 1 & 1 & 2 & 3142 & 0.72 & 1.31 & 1938 & 1.17 & 2.13 & 2258 & 71.88 \\
\hline 1 & 1 & 3 & 3150 & 0.79 & 1.33 & 1941 & 1.28 & 2.16 & 2261 & 71.77 \\
\hline 1 & 2 & 1 & 3176 & 0.93 & 1.49 & 1967 & 1.51 & 2.41 & 2440 & 76.82 \\
\hline 1 & 2 & 2 & 3194 & 0.96 & 1.50 & 1972 & 1.56 & 2.43 & 2446 & 76.59 \\
\hline 1 & 2 & 3 & 3202 & 1.00 & 1.59 & 1975 & 1.63 & 2.57 & 2449 & 76.48 \\
\hline 1 & 3 & 1 & 3226 & 0.97 & 1.54 & 2006 & 1.56 & 2.47 & 2613 & 81.00 \\
\hline 1 & 3 & 2 & 3244 & 1.01 & 1.55 & 2012 & 1.62 & 2.51 & 2620 & 80.76 \\
\hline 1 & 3 & 3 & 3252 & 1.00 & 1.57 & 2015 & 1.61 & 2.54 & 2623 & 80.64 \\
\hline 2 & 1 & 1 & 2728 & 0.74 & 1.45 & 1656 & 1.22 & 2.39 & 2052 & 75.23 \\
\hline 2 & 1 & 2 & 2743 & 0.77 & 1.50 & 1661 & 1.27 & 2.48 & 2058 & 75.01 \\
\hline 2 & 1 & 3 & 2750 & 0.80 & 1.52 & 1664 & 1.32 & 2.51 & 2060 & 74.90 \\
\hline 2 & 2 & 1 & 2812 & 1.02 & 1.56 & 1686 & 1.70 & 2.61 & 2210 & 78.61 \\
\hline 2 & 2 & 2 & 2828 & 1.08 & 1.66 & 1691 & 1.81 & 2.78 & 2216 & 78.38 \\
\hline 2 & 2 & 3 & 2835 & 1.12 & 1.73 & 1694 & 1.87 & 2.90 & 2219 & 78.26 \\
\hline 2 & 3 & 1 & 2892 & 1.08 & 1.66 & 1726 & 1.80 & 2.78 & 2369 & 81.89 \\
\hline 2 & 3 & 2 & 2909 & 1.11 & 1.70 & 1731 & 1.86 & 2.85 & 2375 & 81.65 \\
\hline 2 & 3 & 3 & 2916 & 1.11 & 1.70 & 1734 & 1.87 & 2.85 & 2378 & 81.53 \\
\hline 3 & 1 & 1 & 2410 & 0.74 & 1.19 & 1339 & 1.33 & 2.14 & 1939 & 80.44 \\
\hline 3 & 1 & 2 & 2424 & 0.75 & 1.21 & 1343 & 1.36 & 2.19 & 1944 & 80.20 \\
\hline 3 & 1 & 3 & 2430 & 0.77 & 1.25 & 1345 & 1.39 & 2.25 & 1946 & 80.08 \\
\hline 3 & 2 & 1 & 2465 & 0.74 & 1.19 & 1367 & 1.33 & 2.14 & 2057 & 83.47 \\
\hline 3 & 2 & 2 & 2479 & 0.83 & 1.24 & 1372 & 1.49 & 2.25 & 2063 & 83.22 \\
\hline 3 & 2 & 3 & 2485 & 0.89 & 1.29 & 1374 & 1.62 & 2.34 & 2065 & 83.10 \\
\hline 3 & 3 & 1 & 2519 & 0.84 & 1.36 & 1407 & 1.50 & 2.44 & 2177 & 86.43 \\
\hline 3 & 3 & 2 & 2533 & 0.91 & 1.38 & 1411 & 1.63 & 2.48 & 2183 & 86.17 \\
\hline 3 & 3 & 3 & 2539 & 0.93 & 1.39 & 1413 & 1.67 & 2.51 & 2185 & 86.05 \\
\hline
\end{tabular}

Water Applied (WA), Productivity of Water Applied (PWA), Water Consumptive Use (WCU), Productivity of Water Consumptive Use (PWCU), Stored Water (SW) and Water Application Efficiency (WAE)

The second order interaction among irrigation, $\mathrm{N}$ and $\mathrm{K}$ rate distinctly influenced $\mathrm{AW}$, WCU and SW in both seasons (Tables 7 and 8). Decreasing soil moisture depletion before irrigation along with increasing $\mathrm{N}$ and $\mathrm{K}$ rate substantially increased AW, WCU and SW in both seasons. Abundance of available soil moisture (irrigation at $40 \%$ DASM) with $90 \mathrm{~kg} \mathrm{~N}$ and $24 \mathrm{~kg} \mathrm{~K}_{2} \mathrm{O}$ fed $^{-1}$ produced the highest values of AW (3252 and $3264 \mathrm{~m}^{3} \mathrm{fed}^{-1}$ ), WCU (2015 and $2020 \mathrm{~m}^{3} \mathrm{fed}^{-1}$ ) and SW (2623 and $\left.2693 \mathrm{~m}^{3} \mathrm{fed}^{-1}\right)$. However, irrigation at 70\% DASM with $50 \mathrm{~kg} \mathrm{~N}$ and without $\mathrm{k}$ fertilizer recorded the lowest values of AW (2410 and 2423 $\mathrm{m}^{3} \mathrm{fed}^{-1}$ ), WCU (1339 and $1347 \mathrm{~m}^{3} \mathrm{fed}^{-1}$ ) and SW (1939 and $1956 \mathrm{~m}^{3} \mathrm{fed}^{-1}$ ) in the two seasons.

\section{Water productivity:}

Grain yield per unit of applied water (AW) and water consumptive use (WCU) in $\mathrm{kg}$ grain or straw $\mathrm{m}^{-3}$ water were used to determine water productivity. Data in Table 6 show that water productivity of grain and straw $\left(\mathrm{kg} \mathrm{m}^{-}{ }^{3}\right.$ water) for either AW or WCU was increased by increasing soil moisture depletion from 40 to 55\% DASM at irrigation and then it decreased. This may be due to increase grain and straw yields.

In this connection, Rizk and Sherif (2014) found that the highest value of water use efficiency when irrigation water was applied at $40 \%$ available soil moisture for grain. Guendouz et al (2016) found that water deficit increased water use efficiency. Tari (2016) reported that irrigation water-use efficiencies varied between 0.51 and $1.17 \mathrm{~kg} \mathrm{~m}^{-3}$. These results agree with those of Meleha (2016) and Guendouz et al (2016).

The water productivity of grain and straw for AW and WCU was increased by increasing nitrogen rate from 50 to 90 $\mathrm{kg} \mathrm{N}$ fed ${ }^{-1}$ and potassium rate from 0 to $24 \mathrm{~kg} \mathrm{k}_{2} \mathrm{O}_{\text {fed }}{ }^{-1}$ in both seasons. NK fertilizer increased water productivity through increasing grain and straw yields. In this connection, Gharib and Meleha (2016) found that the water productivity for AW and WCU was slightly increased by application of K fertilizer.

The interaction of irrigation regime and nitrogen rate influenced the water productivity of grain and straw for AW and WCU in both seasons (Tables 7 and 8). The relative ranking of the interaction between irrigation regime and nitrogen rate for water productivity was inconsistent in both seasons. At the same irrigation regime, application of 70 or 90 $\mathrm{kg} \mathrm{N}$ fed $^{-1}$ increased the water productivity of grain and straw for $\mathrm{AW}$ and WCU compared with $50 \mathrm{~kg} \mathrm{~N}$ fed $^{-1}$. Irrigation at $55 \%$ DASM along with addition of 70 or $90 \mathrm{~kg} \mathrm{~N} \mathrm{fed}^{-1}$ were 
among those treatments having high water productivity of grain and straw for AW and WCU in the most cases. Application of 70 or $90 \mathrm{~kg} \mathrm{~N}$ fed $^{-1}$ practically produced the same productivity of grain and straw for AW and WCU at any irrigation regime.

Table 8. Water Applied (WA), Productivity of Water Applied (PWA), Water Consumptive Use (WCU), Productivity of Water Consumptive Use (PWCU), Stored Water (SW) and Water Application Efficiency (WAE) as affected by irrigation regime (depletion \%, D), nitrogen and potassium rates in 2015/2016 season

\begin{tabular}{|c|c|c|c|c|c|c|c|c|c|c|}
\hline D & $\mathbf{N}$ & $\mathbf{K}$ & $\begin{array}{c}\text { WA } \\
\left(\mathbf{m}^{3} / \text { fed }\right)\end{array}$ & $\begin{array}{c}\text { PWA } \\
\left(\mathrm{kg} \text { grain } / \mathrm{m}^{3}\right)\end{array}$ & $\begin{array}{c}\text { PWA } \\
\left(\mathrm{kg} \mathrm{straW} / \mathrm{m}^{3}\right)\end{array}$ & $\begin{array}{c}\text { WCU } \\
\text { (m3/fed) }\end{array}$ & $\begin{array}{c}\text { PWCU } \\
(\mathrm{kg} \text { grain/m³ }\end{array}$ & $\begin{array}{c}\text { PWCU } \\
\left(\mathrm{kg} \mathrm{straw} / \mathrm{m}^{3}\right)\end{array}$ & $\begin{array}{c}\mathbf{S W} \\
\left(\mathbf{m}^{3} / \text { fed }\right)\end{array}$ & $\begin{array}{c}\text { WAE } \\
(\%)\end{array}$ \\
\hline 1 & 1 & 1 & 3140 & 0.71 & 1.15 & 1938 & 1.15 & 1.86 & 2254.3 & 71.78 \\
\hline 1 & 1 & 2 & 3156 & 0.75 & 1.23 & 1942 & 1.22 & 1.99 & 2259.8 & 71.60 \\
\hline 1 & 1 & 3 & 3161 & 0.79 & 1.23 & 1945 & 1.28 & 1.99 & 2263.3 & 71.60 \\
\hline 1 & 2 & 1 & 3193 & 0.95 & 1.31 & 1973 & 1.53 & 2.12 & 2464.7 & 77.19 \\
\hline 1 & 2 & 2 & 3209 & 0.98 & 1.31 & 1978 & 1.59 & 2.13 & 2470.7 & 77.00 \\
\hline 1 & 2 & 3 & 3214 & 0.99 & 1.33 & 1980 & 1.61 & 2.16 & 2474.6 & 77.00 \\
\hline 1 & 3 & 1 & 3243 & 0.95 & 1.35 & 2014 & 1.52 & 2.17 & 2682.2 & 82.70 \\
\hline 1 & 3 & 2 & 3259 & 0.98 & 1.36 & 2018 & 1.59 & 2.20 & 2688.8 & 82.49 \\
\hline 1 & 3 & 3 & 3264 & 1.00 & 1.38 & 2020 & 1.61 & 2.23 & 2693 & 82.49 \\
\hline 2 & 1 & 1 & 2755 & 0.76 & 0.95 & 1665 & 1.27 & 1.57 & 2068.9 & 75.09 \\
\hline 2 & 1 & 2 & 2769 & 0.79 & 0.99 & 1668 & 1.31 & 1.64 & 2074 & 74.91 \\
\hline 2 & 1 & 3 & 2773 & 0.82 & 1.01 & 1670 & 1.37 & 1.67 & 2077.3 & 74.91 \\
\hline 2 & 2 & 1 & 2874 & 1.04 & 1.35 & 1735 & 1.73 & 2.23 & 2263.1 & 78.75 \\
\hline 2 & 2 & 2 & 2888 & 1.07 & 1.43 & 1739 & 1.78 & 2.38 & 2268.7 & 78.55 \\
\hline 2 & 2 & 3 & 2893 & 1.09 & 1.44 & 1741 & 1.82 & 2.40 & 2272.2 & 78.55 \\
\hline 2 & 3 & 1 & 2990 & 1.00 & 1.41 & 1727 & 1.74 & 2.45 & 2453.9 & 82.07 \\
\hline 2 & 3 & 2 & 3005 & 1.06 & 1.44 & 1731 & 1.84 & 2.51 & 2459.9 & 81.86 \\
\hline 2 & 3 & 3 & 3010 & 1.06 & 1.45 & 1733 & 1.85 & 2.52 & 2463.8 & 81.86 \\
\hline 3 & 1 & 1 & 2423 & 0.80 & 1.07 & 1347 & 1.44 & 1.92 & 1956.4 & 80.73 \\
\hline 3 & 1 & 2 & 2435 & 0.81 & 1.08 & 1350 & 1.47 & 1.95 & 1961.2 & 80.53 \\
\hline 3 & 1 & 3 & 2439 & 0.83 & 1.09 & 1352 & 1.50 & 1.97 & 1964.3 & 80.53 \\
\hline 3 & 2 & 1 & 2492 & 0.88 & 1.11 & 1376 & 1.59 & 2.01 & 2092.5 & 83.98 \\
\hline 3 & 2 & 2 & 2504 & 0.95 & 1.16 & 1379 & 1.73 & 2.11 & 2097.6 & 83.77 \\
\hline 3 & 2 & 3 & 2508 & 1.00 & 1.21 & 1380 & 1.82 & 2.20 & 2100.9 & 83.77 \\
\hline 3 & 3 & 1 & 2556 & 0.86 & 1.41 & 1418 & 1.55 & 2.53 & 2223.4 & 86.98 \\
\hline 3 & 3 & 2 & 2569 & 0.93 & 1.53 & 1421 & 1.69 & 2.77 & 2228.8 & 86.77 \\
\hline 3 & 3 & 3 & 2573 & 1.01 & 1.55 & 1423 & 1.82 & 2.81 & 2232.3 & 86.77 \\
\hline
\end{tabular}

Water Applied (WA), Productivity of Water Applied (PWA), Water Consumptive Use (WCU), Productivity of Water Consumptive Use (PWCU), Stored Water (SW) and Water Application Efficiency (WAE)

The interaction between irrigation regime and potassium rate influenced the water productivity of grain and straw for AW and WCU in both seasons (Tables 7 and 8). Application of $\mathrm{K}$ fertilizer slightly increased the water productivity of grain and straw for AW and WCU at the same irrigation regime in the two seasons. Irrigation at $55 \%$ DASM with $24 \mathrm{~kg} \mathrm{~K}_{2} \mathrm{O}$ fed $^{-1}$ markedly increased the water productivity of grain and straw for AW in both seasons and WCU in the first season compared with irrigation at $70 \%$ DASM without $\mathrm{K}$ fertilizer. In the second season, the highest of water productivity of grain and straw for WCU was obtained from irrigation at $70 \%$ DASM with the rate of $24 \mathrm{~kg}$ $\mathrm{K}_{2} \mathrm{O}$ fed $^{-1}$, while the lowest one was obtained from irrigation at $40 \%$ DASM without K fertilizer.

The interaction between nitrogen rate and potassium rate had a substantial effect on the water productivity of grain and straw for AW and WCU in both seasons (Tables 7 and 8 ). The mentioned traits were increased by increasing $\mathrm{NK}$ rate. Application of 90 or $70 \mathrm{Kg} \mathrm{N}$ along with $24 \mathrm{~kg} \mathrm{~K}_{2} \mathrm{O}$ fed ${ }^{1}$ resulted in pronounce increase in the water productivity of grain and straw for AW and WCU compared with $50 \mathrm{Kg} \mathrm{N}$ without $\mathrm{K}$ fertilizer.

The interaction of irrigation $\mathrm{x} \mathrm{N}$ rate $\mathrm{x} \mathrm{K}$ rate had a substantially effect on the water productivity of grain and straw for AW and WCU in both seasons. Irrigation at 55\% DASM with $70 \mathrm{~kg} \mathrm{~N}$ and $24 \mathrm{~kg} \mathrm{~K}_{2} \mathrm{O}$ fed $^{-1}$ produced the highest water productivity values of grain for AW (1.12 and $1.09 \mathrm{~kg}$ grain $\mathrm{m}^{3} \mathrm{AW}$ ), while irrigation at $40 \%$ DASM with
$50 \mathrm{~kg} \mathrm{~N}$ and without $\mathrm{K}$ fertilizer $\left(0.68\right.$ and $0.71 \mathrm{~kg}$ grain $\mathrm{m}^{3}$ $\mathrm{AW}$ ) in the two seasons. Irrigation at 55\% DASM with 70 or $90 \mathrm{~kg} \mathrm{~N}$ and 12 or $24 \mathrm{~kg} \mathrm{~K}_{2} \mathrm{O}$ fed $^{-1}$ did not differ in the productivity of grain for AW than Irrigation at 55\% DASM with $70 \mathrm{~kg} \mathrm{~N}$ and $24 \mathrm{~kg} \mathrm{~K}_{2} \mathrm{O}$ fed $^{-1}$ in both seasons. In the first season, Irrigation at 55\% DASM with $70 \mathrm{~kg} \mathrm{~N}$ and $24 \mathrm{~kg}$ $\mathrm{K}_{2} \mathrm{O}$ fed $^{-1}$ produced the highest water productivity values of grain for WCU $\left(1.73 \mathrm{~kg}\right.$ grain $\left.\mathrm{m}^{3} \mathrm{WCU}\right)$, while irrigation at $40 \%$ DASM with $50 \mathrm{~kg} \mathrm{~N}$ and without K fertilizer $(1.19 \mathrm{~kg}$ grain $\left.\mathrm{m}^{3} \mathrm{WCU}\right)$. Irrigation at $55 \% \mathrm{DASM}$ with either combination of 70 or $90 \mathrm{~kg} \mathrm{~N}$ and $24 \mathrm{~kg} \mathrm{~K}_{2} \mathrm{O}_{\text {fed }}{ }^{-1}$ or 70 or 90 $\mathrm{kg} \mathrm{N}$ and 12 or $24 \mathrm{~kg} \mathrm{~K}_{2} \mathrm{O}$ fed $^{-1}$ practically produced the same productivity of grain for WCU Irrigation in the first seasons. The relative ranking of the interaction among irrigation regime, nitrogen rate and potassium rate for water productivity of straw for AW was inconsistent in both seasons. In the first season, Irrigation at 55\% DASM with 70 $\mathrm{kg} \mathrm{N}$ and $24 \mathrm{~kg} \mathrm{~K}_{2} \mathrm{O}$ fed $^{-1}$ produced the highest water productivity values of straw for AW (1.73 $\mathrm{kg}$ straw $\left.\mathrm{m}^{3} \mathrm{AW}\right)$, while irrigation at $40 \%$ DASM with $50 \mathrm{~kg} \mathrm{~N}$ and without $\mathrm{K}$ fertilizer $\left(1.19 \mathrm{~kg}\right.$ straw $\left.\mathrm{m}^{3} \mathrm{AW}\right)$. Irrigation at $55 \%$ DASM with either combination of 70 or $90 \mathrm{~kg} \mathrm{~N}$ and $24 \mathrm{~kg} \mathrm{~K}_{2} \mathrm{O}$ fed $^{-}$ ${ }^{1}$ or 70 or $90 \mathrm{~kg} \mathrm{~N}$ and 12 or $24 \mathrm{~kg} \mathrm{~K}_{2} \mathrm{O}$ fed ${ }^{-1}$ practically produced the same productivity of straw for AW in the first seasons. The water productivity of grain or straw for AW was increased at 70 or $90 \mathrm{~kg} \mathrm{~N}$ fed $^{-1}$ with any potassium rate by increasing soil moisture depletion at irrigation from 40 to $55 \%$ DASM and then it decreased. 
The water productivity of grain and straw for WCU as affected by the interaction of irrigation, nitrogen rate and potassium rate are presented in Tables 7 and 8 . Increasing soil moisture depletion at irrigation from 40 to 55\% DASM at any combination of NK fertilizer markedly increased the water productivity of grain for WCU and then decreased it in both seasons. Irrigation at 55\% DASM along with addition of 70 or $90 \mathrm{~kg} \mathrm{~N}$ fed $^{-1}$ and 12 or $24 \mathrm{~kg} \mathrm{~K}_{2} \mathrm{O}$ fed $^{-1}$ were among those treatments having high water productivity of grain for WCU in the two seasons. The water productivity of grain for WCU ( $\mathrm{kg}$ grain $\mathrm{m}^{3} \mathrm{WCU}$ ) was ranged from 1.19 to 1.73 in the first season and from 1.15 to 1.85 the second season.

\section{Water application efficiency $\%$}

The percentage of water application efficiency (WAE) was substantially increased by decreasing amount of applied water by irrigation at $70 \%$ DASM in both seasons (Table 6). This may be due to decreased WCU at $70 \%$ DASM.

Increasing nitrogen rate from 50 to $90 \mathrm{~kg} \mathrm{~N}$ fed $^{-1}$ gradually increased WAE\% in both seasons. Application of $90 \mathrm{~kg} \mathrm{~N}$ fed $^{-1}$ recorded the highest values of WAE \%, while Application of $50 \mathrm{~kg} \mathrm{~N}$ fed $^{-1}$ recorded the lowest ones. This may be due to increased AW at the high $\mathrm{N}$ rate.

Application of potassium fertilizer had slightly effect on the percentage of WAE in the two seasons.

The interaction of irrigation regime and nitrogen rate influenced the percentage of WAE in both seasons (Tables 7 and 8). Data show that increasing soil moisture depletion at irrigation along with increasing nitrogen rate exerted a marked increase in WAE \% in the two seasons. The highest values of WAE\% were obtained from irrigation at $70 \%$ DASM with application of $90 \mathrm{~kg} \mathrm{~N} \mathrm{fed}^{-1}$, while the lowest ones were obtained from irrigation at $40 \%$ DASM with application of $50 \mathrm{~kg} \mathrm{~N} \mathrm{fed}^{-1}$.

The interaction between irrigation regime and potassium rate influenced the WAE \% in both seasons (Tables 7 and 8). At the same irrigation regime, WAE \% did not affect by application of $\mathrm{K}$ fertilizer in the two seasons. In the contrary, decreasing amount of AW by increasing soil moisture depletion from 40 to $70 \%$ at irrigation substantially increased $\mathrm{WAE} \%$ at any $\mathrm{K}$ fertilizer rate. This indicated that irrigation regime more effective than potassium fertilizer on WAE \%.

WAE\% was pronouncedly influenced by the interaction between nitrogen rate and potassium rate in both seasons (Tables 7 and 8). Application of $\mathrm{K}$ fertilizer had inferior effect on $\mathrm{WAE} \%$ at the same nitrogen rate in the two seasons. However, WAE\% was increased by increasing nitrogen rate at any potassium rate in the two seasons.

The interaction among irrigation regime, nitrogen rate and potassium rate had a substantially effect on WAE\% in both seasons (Tables 7 and 8). Potassium fertilizer had a slightly effect on WAE\% at the same combination of irrigation regime and nitrogen rate in the two seasons. However, increasing of soil moisture depletion at irrigation with increasing nitrogen rate increased $\mathrm{WAE} \%$ at the same potassium rate. Irrigation at $70 \%$ DASM with $90 \mathrm{~kg} \mathrm{~N}$ and 0 $\mathrm{kg} \mathrm{K}_{2} \mathrm{O}$ fed $^{-1}$ produced the highest values of WAE ( 86.43 and $86.98 \%$ ), while irrigation at $40 \%$ DASM with $50 \mathrm{~kg} \mathrm{~N}$ and $24 \mathrm{~kg}$ K2O fed-1 produced the lowest values (71.77 and 71.60 $\%)$ in the two seasons.
It can be concluded that irrigation at 55\% DASM with application of $70 \mathrm{~kg} \mathrm{~N}$ and 12 or $24 \mathrm{~kg} \mathrm{~K}_{2} \mathrm{O}$ fed $^{-1}$ was the best treatment, which resulted in high grain yield with less amount of applied irrigation water (1.12 and $1.09 \mathrm{~kg}$ grain $\mathrm{m}^{3} \mathrm{AW}$ ), and water consumptive use $\left(1.73 \mathrm{~kg}_{\text {grain }} \mathrm{m}^{3} \mathrm{WCU}\right)$ in Kafr Elshiekh Governorate.

\section{REFERENCES}

Abedi, T.; A. Alemzadeh and S.A. Kazemeini (2011). Wheat yield and grain protein response to nitrogen amount and timing. A. J. Crop Sci., 5(3):330-336.

Ali, N. (2013). Response of wheat to mineral nitrogen fertilizer and biofertilizer (Azotobactersp. and Azospirillumsp.) inoculation under different levels of weed interference Ekologija. Vol. 59.No. 2. P. 85-94

Attia, M. and M. Barsoum (2013). Effect of supplementary irrigation and bio-fertilization on wheat yield productivity under rainfed conditions. J. Agric. Res., (58): 49-57.

Dogan, R. and U. Bilgili ( 2010). Effects of previous crop and $\mathrm{N}$-fertilization on seed yield of winter wheat (Triticum aestivum L.) under rain-fed Mediterranean conditions. Bulgarian Journal of Agricultural Science, 16: 733739

Duncan, B.D. (1955). Multiple range and multiple F tests. Biometrics 11: 1-42.

El-Ashry, M. and M. El-Kholy (2005). Response of wheat cultivars to chemical desiccants under water stress conditions. J. of Appl. Sci. Res, (1): 253-262.

EL-Hag, Dalia,. A.A. (2012). Effect of planting date and nitrogen level on yield and quality of bread and durum wheat. Ph.D. Thesis, Agronomy Department, Faculty of Agric, Kaferelshikh Univ., Egypt.

EL-Hag, Walaa, A.A. (2011). Evaluation of some cultivars and lines of bread wheat under low input. M. Sc. Thesis, Kaferelshikh Univ., Egypt.

El-Samahy-Basma E.S.M (2009). Effect of nitrogen, potassium Fertilizar on yield and componentes of some wheat genotypes. M.Sc. Thesis, Kafrelsheikh Univ., Egypt.

El-Sayed, Soad, A. and S.M. Hammad. (2007). Effect of nitrogen and potassium levels on agronomic and quality traits in three bread wheat cultivars. J. Agric. Sci., Mansoura Univ., 32(7):5139-5153.

Gharib, H. S. and M.E. Meleha (2016). The Mutual Effect of Withholding Irrigation at Some Growth Stages and Potassium Fertilizer on Yield and Water Productivity of Wheat. J. Plant Production, Mansoura Univ., 7 (12):1303 -1313.

Gomez, K.A. and A.A., Gomez (1984). Statistical procedures for agricultural research. An International Rice Research Institute Book John Willey and Sons. Inc., New Yourk.

Guendouz, A.; N. Semcheddine; L. Moumeni and M. Hafsi (2016). The effect of supplementary irrigation on leaf area, specific leaf weight, grain yield and water use efficiency in durum wheat (Triticum durum desf.) cultivars. Ekin J, (2): 82- 89.

Hafez, E.M. (2007). Effect of some agricultural practices on growth and productivity of wheat. M.Sc. Thesis, Kafr El-Shekh Univ., Egypt.

Israelson, O.W. and V.E. Hansen (1962). Irrigation principles and practices. 3rd Edit. John Willey and Sons, Inc. New York. 
Ivanova, A., M. Nankova and N. Tsenov, (2007). Effect of previous crop, mineral fertilization and enviroment on the characters of new wheat varieties. Bulgarian Journal of Agricultural Science, 13 (1): 55-62.

Jacob T. Bushong, D. Brian Arnall and William R . Raun. (2014). Effect of Preplant Irrigation, Nitrogen Fertilizer Application Timing, and Phosphorus and Potassium Fertilization on Winter Wheat Grain Yield and Water Use Efficiency. International Journal of Agronomy, Volume 2014, Article ID 312416, 12 pages. http://dx.doi.org/10.1155/2014/312416

Javaid I.; K. Hayat; S. Hussain; A. Ali and M. Ahmad ;A. Bakhsh (2014). Effect of Seeding Rates and Nitrogen Levels on Yield and Yield Components of Wheat (Triticumaestivum L.) Pakistan Journal of Nutrition 11 (7): 531-536,

Jazy, H. D.; K. N. Namini and M. Ameri(2012).Effect of deficit irrigation regimes on yield, yield components and some quality traits of three bread wheat cultivars (Triticum aestivum 1.).Int. J.Agri. Crop Sci.,(4):234-237

Karim, A.J.M.S., K. Egashira and M.J. Abedin (1997). Interaction effects of irrigation and nitrogen fertilization on yield and water use of wheat grown in a clay terrace soil in Bangladesh. Bull. Inst. Tropical Agric., 20: 17-26

Li, Q.; Ch. Bian; X. Liu; Ch. Ma and Q. Liu (2015). Winter wheat grain yield and water use efficiency in wideprecision planting pattern under deficit irrigation in North China Plain, Agricultural Water Mana, 153 (2015) 71-76.

Liu, D. and Y. Shi (2013). Effects of different nitrogen fertilizer on quality and yield in winter wheat. Advance Journal of Food Science and Technology, 5 (5): 646-649

Mekkei, M. E. R. and E. A. M. A. El Haggan (2014). Effect of different irrigation regimes on grain yield and quality of some Egyptian bread wheat cultivars. J. Agri-Food Appl. Sci., (2): 275-282.

Meleha, A. M. I. (2016). Effect of irrigation water management on wheat yield. Ph.D. Thesis, Fac., Agric., Kafrelsheikh Univ., Egypt.

Michael, A. M. (1978). Irrigation theory and practice. Vikas publishing House PVT. Ltd.

Mirbahar, A. A.; G. Markhand; A. Mahar; S. A. Abro and N. A. Kanhar (2009). Effect of water stress on yield and yield components of wheat (Triticum aestivumL.) varieties. Pak. J. Bot, (41): 1303- 1310.
Mosaad I. S.and K. F. Fouda (2016) Effect of potassium and nitrogen fertilization on some macronutrients utilization efficiency by wheat. egypt. J. Soil. Sci, 56(3); 373- 384

Ngwako , S. and P. K. Mashiqa (2013). The effect of irrigation on the growth and yield of winter wheat (Triticum aestivum L.) cultivars , Intl. J. Agric. Crop Sci. , 5 (9), 976-982.

Rahimi, A. (2012) Effect of potassium and nitrogen on yield and yield components of dry land wheat in Boyerahmad Region of Iran. Annals of Biol. Res., 3 (7), 3274;3277.

Rizk, A. H. and M. M. Sherif (2014) . Effect of soil moisture depletion on the yield of wheat under sprinkler irrigation at toshka area, egypt. Middle East J. Agric. Res., (3): 981 -987.

Shirazi, M.; M. Khan; N. Bhatti; A. Unar; H. Bozdar; S. Mujtaba and M. Lashari (2014). Growth and water use efficiency in wheat genotypes grown under water stress condition. E3 J. Agric. Res. Develop, (4): 023028.

Sun, H.Y., C.M. Liu, X.Y. Zhang, Y.J. Shen and Y.Q. Zhang(2006). Effects of irrigation on water balance, yield and WUE of winter wheat in the North China Plain. Agricultural Water. Management, 85: 211-218.

Tari, A. F. (2016). The effects of different deficit irrigation strategies on yield, quality, and water use efficiencies of wheat under semi-arid conditions. Agric. Water Manage., (167): 1 -10.

Zareian, A.; H. Abad and A. Hamidi (2014). Yield, yield components and some physiological traits of three wheat (Triticum aestivumL.) cultivars under drought stress and potassium foliar application treatments. Int. J. Biosci., (4): 168-175.

Zeidan, E.M.; I.M. Abd El-Hameed; A. H. Bassiouny and A.A. Waly (2009). Effect of irrigation intervals, nitrogen and organic fertilization on yield, yield attributes and crude protein of some wheat cultivars under newly reclaimed saline soil conditions. $4^{\text {th }}$ Conference on Recent Technologies in Agriculture 2009.

Zhang, X.Y., D. Pei, S.Y. Chen, H.Y. Sun and Y.H. Yang, 2006. Performance of double-cropped winter wheatsummer maize under minimum irrigation in the North China Plain. Agronomy Journal, 98: 1620-1626.

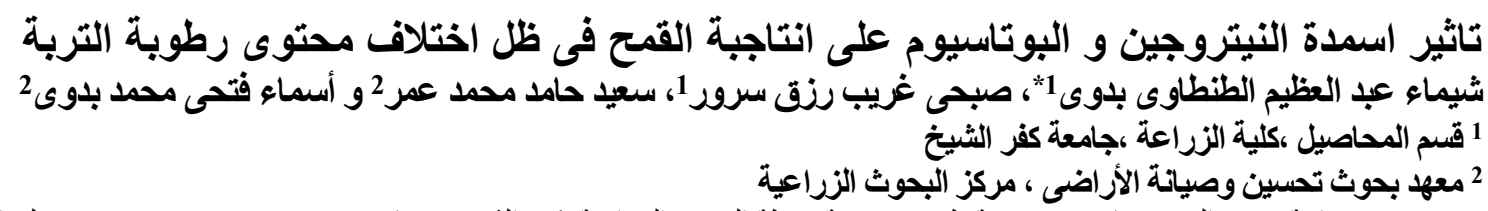

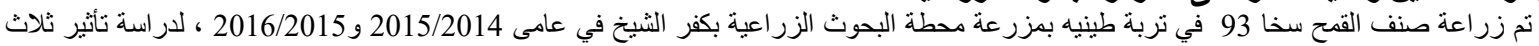

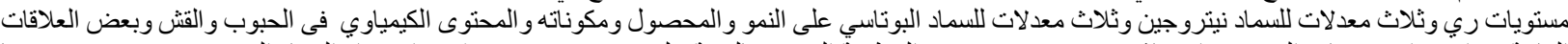

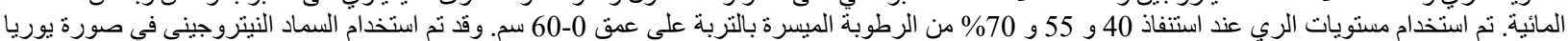

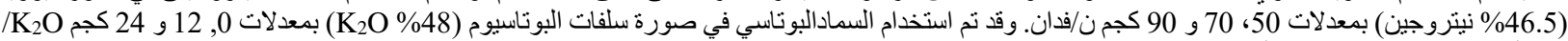

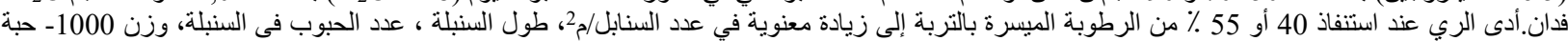

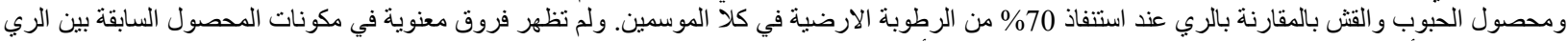

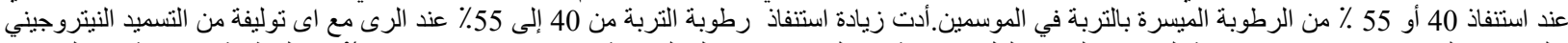

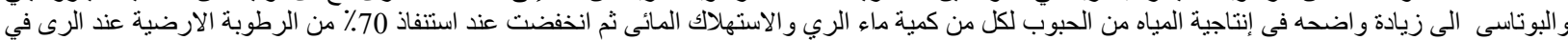

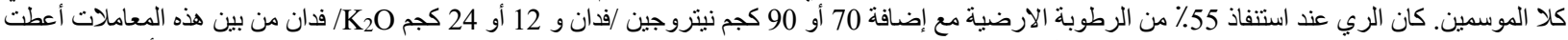

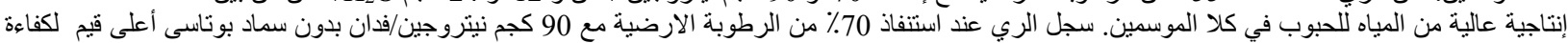

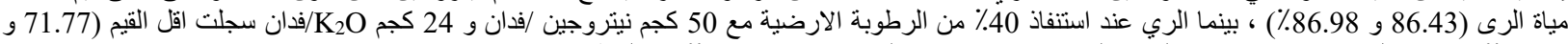

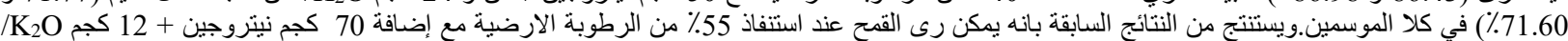
فدان للحصول على اعلى إنتاجية محصول حبوب القمح في محافظة كفر الثيخ. 